\title{
Philosophy of the City
}

Mathew Crippen*, Vladan Klement

\section{Architectural Values, Political Affordances and Selective Permeability}

https://doi.org/10.1515/opphil-2020-0112

received April 21, 2020; accepted July 21, 2020

\begin{abstract}
This article connects value-sensitive design to Gibson's affordance theory: the view that we perceive in terms of the ease or difficulty with which we can negotiate space. Gibson's ideas offer a nonsubjectivist way of grasping culturally relative values, out of which we develop a concept of political affordances, here understood as openings or closures for social action, often implicit. Political affordances are equally about environments and capacities to act in them. Capacities and hence the severity of affordances vary with age, health, social status and more. This suggests settings are selectively permeable, or what postphenomenologists call multistable. Multistable settings are such that a single physical location shows up differently - as welcoming or hostile - depending on how individuals can act on it. In egregious cases, authoritarian governments redesign politically imbued spaces to psychologically cordon both them and the ideologies they represent. Selective permeability is also orchestrated according to business interests, which is symptomatic of commercial imperatives increasingly dictating what counts as moral and political goods.
\end{abstract}

Keywords: architectural values, moral and political philosophy, multistability, political affordances, postphenomenology, pragmatism, selective permeability, sociology of place, urban planning, valuesensitive design

\section{Introduction}

Everyday life is valuative, that is, organized around emotions, interests and aesthetics. ${ }^{1}$ The behavioral neuroscientist and philosopher Jay Schulkin, for example, identifies emotion with cognitive systems that "pervade aesthetic judgment."2 The environmental psychologists Rachel and Stephen Kaplan similarly argue that aesthetic and affective sensitivities to environments undergird cognition and perception. ${ }^{3}$ They locate their position loosely within J. J. Gibson's ecological psychology, which is increasingly cited by urban researchers. ${ }^{4}$

1 For example, Damasio, Descartes' Error: Emotion, Reason, and the Human Brain; Johnson, The Aesthetics of Meaning and Thought; Schulkin et al., "Demythologizing the Emotions: Adaptation, Cognition, and Visceral Representations of Emotion in the Nervous System."

2 Schulkin, Bodily Sensibility: Intelligent Action, 57.

3 See Kaplan and Kaplan, The Experience of Nature.

4 For example, Maier et al., “An Affordance-Based Approach to Architectural Theory, Design, and Practice;" Marcus, "Overcoming the Subject-Object Dichotomy in Urban Modeling: Axial Maps as Geometric Representations of Affordances in the

* Corresponding author: Mathew Crippen, Pusan National University, Busan, Republic of Korea; Berlin School of Mind and Brain, Humboldt-Universität zu Berlin, Germany, e-mail: matthewjcrippen@gmail.com

Vladan Klement: Masaryk University, Brno, Czech Republic, e-mail: vladanklem@gmail.com 
Elaborating on these lines of thinking, we advance three interconnected points. First, we expand the value-sensitive design approach: a framework that holds that human artifacts embody political and ethical values, accounting for this throughout the design process. ${ }^{5}$ Thus, for example, marble in financial institutions signifies trustworthiness, reliability and security, ${ }^{6}$ along with prestige and wealth. These values have social implications, organizing human movements by inviting certain people in to do business and perhaps warding off those of modest means. This immediately suggests architectural structures are selectively permeable.

A second line of argument introduces Gibson's affordance theory. Gibson emphasizes that we perceive in terms of the ease or difficulty with which we can navigate and handle affairs in settings ${ }^{7}$ and further that any layout "has some affordance for benefit or injury,"8 meaning environments have values. Merging Gibson's position and value-sensitive design with defensible space theory, which stresses latent boundaries that corral human movements in urban space, we develop a concept of political affordances - understood as openings or closures for political action. Recent studies affirm that health, fatigue, mood and suchlike affect how affordances show up. ${ }^{9}$ This makes sense insofar as these variations correlate with action capacity, and hence what a setting affords. It therefore stands to reason that cultural factors such as political exhaustion can modulate affordances. This, in turn, suggests a nonsubjective understanding of culturally relative values. ${ }^{10}$ After all, the walkability that water affords to some insects is not a mental variation, nor is it merely subjective that dung has nutritional value for certain animals, but not for humans. ${ }^{11}$ We assert that cultural environments afford values in comparable ways. This might be such that women see a setting as more threatening by virtue of it posing more objective risk to them than it does to men. Citizens of an authoritarian regime may likewise face more danger than tourists and hence register a space differently. This is just as a shared environment differentially affects people depending on age.

A third line of argument specifically attends to selective permeability, a concept we augment with postphenomenological discussions of multistability: the idea that objects manifest according to how people can engage with them. An extreme example is New York City planner Robert Moses strategically locating low overpasses to hinder bus movement to Jones Beach from poor and especially black neighborhoods. ${ }^{12}$ Though some challenge this account, ${ }^{13}$ comparable examples abound: planners regularly include features thwarting skateboarding; ${ }^{14}$ affluent and mostly white residents of an Atlanta suburb petitioned against subway expansion that would open their neighborhood to poorer minorities; ${ }^{15}$ there are additional cases of design either cultivating or frustrating protest

Built Environment;” Clark and Uzzell, “The Socio-Environmental Affordances of Adolescents' Environments;” Rivlin, “Found Spaces: Freedom of Choice in Public Life.”

5 For example, Friedman et al., "Value Sensitive Design and Information Systems."

6 Shah and Kesan, "How Architecture Regulates," 351.

7 Gibson, The Ecological Approach to Visual Perception.

8 Ibid., 140.

9 For example, Bhalla and Proffitt, "Visual-Motor Recalibration in Geographical Slant Perception;" Proffitt, "Embodied Perception and the Economy of Action;” Riener et al., "An Effect of Mood on the Perception of Geographical Slant.” Schnall et al., "Direct Evidence for the Economy of Actions: Glucose and the Perception of Geographical Slant;" Zadra et al., "Direct physiological evidence for the economy of action: Bioenergetics and the Perception of Spatial Layout."

10 For a subjectivist account of morality, see Prinz, Emotional Construction of Morals. In the conclusion, we defend Prinz's culturally relativism but attempt to amend it with Gibson's antisubjective theory of values.

11 Crippen, "Embodied Cognition and Perception: Dewey, Science and Skepticism;" Crippen, “Aesthetics and Action" (Synthese online first), Section 5.

12 Caro, The Power Broker: Robert Moses and the Fall of New York; Winner, "Do Artifacts have Politics?"

13 For example, Joerges, "Do Politics Have Artefacts?"

14 See Chellew, “Defending Suburbia: Exploring the Use of Defensive Urban Design Outside of the City Centre;” Németh, “Conflict, Exclusion, Relocation: Skateboarding and Public Space;” Rosenberger, "Why It Takes Both Postphenomenology and STS to Account for Technological Mediation The Case of LOVE Park."

15 Schindler, “Architectural Exclusion: Discrimination and Segregation Through Physical Design of the Built Environment.” 
actions. ${ }^{16}$ Classic literature on implicit boundaries already details how urban form can selectively invite people licensed to be there, while repelling those who are not. ${ }^{17}$ Clearly, then, a single physical location can vary for different individuals who do not encounter the same openings and constraints.

We focus on design that sorts people according to social status, which can relate to fatigue levels, in turn enhancing or diminishing latent closures for action. ${ }^{18}$ Certain measures also filter by age, ${ }^{19}$ as when painful ultrasonic sounds only audible to youths push them away, almost weaponizing space. ${ }^{20}$ We frame this as an overmanagement of urban environments. In egregious cases, authoritarian governments redesign urban settings to psychologically repel citizens and seize control of ideologies represented in politically charged spaces. These practices, however, are only variations of today's market-oriented design aimed at controlling human movement for business purposes and signaling an all-too-tight identification of commercial interests with visions of the moral and political good.

\section{Architectural values}

Artifacts are designed for purposes and hence laden with values; in this case, use values. Though there are relatively few human values bereft of cultural import, some artifacts carry emphatically social values. For example, a dining table might lay weight on the value of gathering as a family for a meal; garden cities of the early 20th century reflect the value that low-income families are entitled to green spaces; ${ }^{21}$ and Notre Dame Cathedral expresses a more politically charged statement about God's majesty and the encompassing wealth and power of the Catholic Church. Though not originally focused on architecture and urban design, value-sensitive design research attends to matters of this sort.

A commonly embedded value is defensibility or hostility. Architectural target hardening in fortress castles exemplifies the point. As Edmund Bacon elaborates, lower levels of these structures are "completely dominated by the need to resist the hostile environment outside."22 There are limited entrances, no windows and rugged surfaces designed to deflect missiles. The arrangement is inward looking and convex, aimed at delivering "the minimum surface exposure for the maximum interior volume." ${ }^{23}$ At higher levels less vulnerable to intrusion, the design becomes more delicate; windows and ornamentation are common, and airy spires almost melt into the surroundings. Features from feudal architecture are incorporated into contemporary design, and here psychological hostility can replace physical hostility, even if the results are aesthetically pleasing. ${ }^{24}$ For instance, architects appear to have modelled the Harold Washington Library Center in Chicago after Renaissance buildings such as the Medici-Riccardi Palace, a private structure designed to repel outside intrusion. As with the palace and Bacon's castle, this public library opens at higher levels, with cascading windows and delicate brickwork. Also mirroring the palace and castle, the library's appearance is fortified at the street level, with heavy

16 For example, Chellew, "Defending Suburbia;" Crippen, "Contours of Cairo Revolt: Semiology and Political Affordances in Street Discourses” (Topoi online first); Crippen, "Body Politics: Revolt and City Celebration;” Jacobs, The Death and Life of Great American Cities, 118-25.

17 Jacobs, The Death and Life of Great American Cities; Newman, Defensible Space: Crime Prevention through Urban Design, throughout; Whyte, The Social Life of Small Urban Spaces.

18 Crippen, "A Tale of Two or Three Cities;" Crippen, "Contours of Cairo Revolt," Section 5.

19 For example, Klement, "Moral and Political Implications of Urbanism;” Klement, "Tools for Shaping Human Behavior in Public Spaces: Theory and Praxis."

20 See Akiyama, "Silent Alarm: The Mosquito Youth Deterrent and the Politics of Frequency;" Klement, "Moral and Political Implications of Urbanism;” Petty, “The London Spikes Controversy: Homelessness, Urban Securitisation and the Question of 'Hostile Architecture'."

21 Van den Hoven, “Architecture and Value-Sensitive Design,” 136.

22 Bacon, Design of Cities, 44.

23 Ibid., 44.

24 Crippen, “Contour of Cairo Revolt;” Crippen, “Intuitive Cities;” Newman, Defensible Space. 
masonry, tiny windows and small elegant brass doors that resemble entrances to an exclusive hotel. One doubts whether people casually passing by feel pulled into this public building. Insofar as the architecture psychologically pushes people away, the outcome mirrors physically hostile design. This includes "antihomeless" spikes intended to prevent sitting or reclining or sprinklers that turn on at night with the partial aim of deterring people from sleeping in parks. ${ }^{25}$

Oscar Newman - both lauded ${ }^{26}$ and reviled ${ }^{27}$ - has prominently deployed psychological measures to indicate that space is under the control of certain groups and to make outsiders feel conspicuous, all in an effort to reduce crime. Newman focuses on inner-city housing projects, where monolithic high rises can be accessed directly from public grounds; and with no intermediary zones marking the transition from public to private territory, residents are unlikely to spot or feel entitled to question intruders; intruders are also unlikely to feel they are penetrating private territory. ${ }^{28}$ Newman suggests ameliorating the situation by incorporating markers - what are in effect symbolic affordances - that communicate the progression into increasingly private space. Measures might include a curb, followed by a decorative fence and a lawn, with a walkway leading to a lobby. An intruder moving through these zones will feel increasingly conspicuous and be increasingly pronounced to inhabitants and thus subject to their questions. "Design," as Newman sums up, "can make [...] both inhabitant and stranger [...] perceive that an area is under the undisputed influence of a particular group."29

Newman draws heavily on Jane Jacobs's ideas about latent divisions between public, semiprivate and private space, albeit neglecting her preference for mixed residential-commercial arrangements and her claim that strangers must feel welcome if cities are to be livable. ${ }^{30}$ Interestingly, Newman was possibly influenced by Martin Heidegger and Maurice Merleau-Ponty. ${ }^{31}$ In line with this, his landmark book Defensible Space almost conceives urban space phenomenologically and unequivocally understands it in prereflective terms. Newman specifically proposes a model that inhibits crime by cultivating "an environment in which latent" - in other words, prereflective - "territoriality and sense of community [...] can be translated into [...] a safe, well-maintained living space." ${ }^{32}$ In Newman's view, a neighborhood is in good order when residents recognize people living on the block, and when, in his words, "strangers to the street are greeted by questioning glances and a cacophony of barking dogs." ${ }^{33}$ Newman thus places soldierly value on defense, which, according to one critic, essentially replaces the "fortress apartment" and "hard walls and locks" with "a soft bunker [...] network of defensible territories."34

Though Newman's principles have yielded crime reductions in some ill-designed neighborhoods, ${ }^{35}$ he can be criticized for talking as if cities are war zones in order to literally and intellectually sell his designs. Newman places value on private control, thereby emphasizing neoliberal values. ${ }^{36}$ It may be worse than this. Some scholars maintain that Newman's vision - or ones like it - recalls gang turf systems. ${ }^{37}$ Others highlight parallels to Michel Foucault's critique of the panopticon, that is, social arrangements that make people feel as if they are controlled and surveilled. ${ }^{38}$ None of this repudiates Newman's evidence that his

25 See Chellew, “Defending Suburbia;” Petty, “The London Spikes Controversy;” Schindler, “Architectural Exclusion.”

26 Without wholly endorsing Newman, Katyal emphasizes merits in his "Architecture as Crime Control."

27 For example, Knoblauch, "The Economy of Fear: Oscar Newman Launches Crime Prevention through Urban Design (1969-197x)."

28 Newman, Creating Defensible Space.

29 Ibid., 2-3.

30 See Jacobs, The Death and Life of Great American Cities.

31 Knoblauch, "The Economy of Fear," 348.

32 Newman, Defensible Space, 3.

33 Ibid., 60.

34 Knoblauch, “The Economy of Fear," 337.

35 See, for example, Newman, Creating Defensible Space.

36 Chellew, "Defending Suburbia;" Smith and Walters, "Desire Lines and Defensive Architecture in Modern Urban Environments."

37 Crippen, "Intuitive Cities;” Jacobs, The Death and Life of Great American Cities.

38 Katyal, “Architecture as Crime Control," 1044-5, 1131-3; Knoblauch, "The Economy of Fear," 345; Shah and Kesan, "How Architecture Regulates,” 353-4; also see Foucault, Discipline and Punish: The Birth of the Prison, esp. 195-228. 
measures decreased crime. Nor do the just mentioned objections deny that his model is better than razor wire and security patrols if these two options are the only avenues for reducing violence in an ill-designed neighborhood. The problems raised, however, highlight ways in which the design embodies personal, economic and cultural values of planners and policy makers - values that are often held with little awareness and therefore uncritically.

One more illustration solidifies the point. This is the Administration Building on the new campus at the American University in Cairo, which closely mirrors features in the earlier discussed fortress castle. To begin with, there is only one entry point from the main plaza. Getting to it entails crossing over what looks like a drawbridge with a moat below, albeit without water. Entering the building, one goes through what resembles a castle gatehouse, complete with the arched opening that would normally hold a spiked portcullis. Upper levels have windows that look like arrow slits, and the roof has protrusions resembling battlements. The combination of features generates a subtle military aesthetic, and it reflects values of the university and country, though one doubts this is intentional. Egypt has been ruled by authoritarian regimes since its independence in 1952. Universities themselves are medieval institutions organized around feudal styles of administration. The American University in Cairo takes this to extremes. One example is President Francis J. Ricciardone hosting an event with U.S. Secretary of State Mike Pompeo, with only secretly preinvited individuals attending. ${ }^{39}$ This had the effect of precluding tough questions to a man who is unpopular in the Middle East because of his advocacy for military aggression, secret prisons and torture, among other things. Another example was former President Lisa Anderson hosting an event with one of Muammar Gaddafi's sons and making attendees submit written questions, which she vetted to ensure only friendly ones..$^{40}$

Langdon Winner captures the overall situation, writing that "many of the most important examples of technologies that have political consequences are those that transcend the simple categories of 'intended' and 'unintended' altogether." He goes on:

These are instances in which the very process of technical development is so thoroughly biased in a particular direction that it regularly produces results counted as wonderful breakthroughs by some social interests and crushing setbacks by others. In such cases it is neither correct nor insightful to say, "Someone intended to do somebody else harm." Rather, one must say that the technological deck has been stacked long in advance to favor certain social interests, and that some people were bound to receive a better hand than others. ${ }^{41}$

The point is that human artifacts - including architecture and urban design - are not ethically and politically neutral. They instead manifest values - values that we often barely notice because they are ingrained in our worlds and cultural habits.

\section{Political affordances and normative space}

In The Ecological Approach to Visual Perception, Gibson describes affordances as openings or closures for action, arguing that we perceive the world in terms of how we can handle things and move, and the ease with which we can do so. In his own words, "Animals need to perceive the affordances of substances, their... values or utilities." ${ }^{42}$ This highlights the psychology of values Gibson had moved toward by the end of his life. ${ }^{43}$ His last book states that environments have "some affordance for benefit or

39 "Letter to the BoT and President Ricciardone" (internal AUC communication, Jan. 14, 2019); also see Walsh, "Revolt at American University Where Pompeo Addressed Middle East.”

40 Personal communication from an attendee who, with others in the Libyan refugee community, submitted questions. We keep the person's identity anonymous to protect his or her job at AUC.

41 Winner, "Do Artifacts have Politics?" 125-6.

42 Gibson, The Ecological Approach to Visual Perception, 97.

43 Reed, James J. Gibson and the Psychology of Perception, 296. 
injury." 44 Gibson concludes that perceiving "an affordance is not a process of perceiving a value-free physical object," with "meaning [...] somehow added;" it entails "a value-rich ecological object." 45

Gibson's affordance theory is applied fairly regularly to urban space, ${ }^{46}$ which obviously offers openings and closures for movement. His work has also been used to characterize social space. ${ }^{47}$ Gestures, for example, are avenues for social action, as when reaching to grasp an extended hand. Standing up can conversely close social space, leading us to cut short a conversation and withdraw, even while not physically preventing us from remaining. The thesis that affordances can be social reiterates their valuative sides. The "Babies of the Borough" initiative, executed in Southeast London, serves to illustrate how something in the vein of social affordances can modulate normative behavior in urban settings. ${ }^{48} \mathrm{As}$ the name suggests, round baby faces with huge eyes were painted on shop shutters to evoke caring feelings and thereby lessen aggression. A government web page boasts that the aim is to use "behavioural insights to reduce anti-social behavior," a claim getting unwittingly close to dystopian novels about social engineering such as A Clockwork Orange. The same site claims a 24\% reduction in "anti-social" activities such as vandalism. ${ }^{49}$

What we want to argue is that urban and hence social space are delineated by what we call "political affordances," which are roughly defined as openings and closures for political action and ultimately normative visions for particular societies, often implicit. As a case study, let us consider Cairo's Tahrir Square, the sentimental heart of Egypt's 2011 Arab Spring and January Revolution. Tahrir means "liberation," and the square got its name with the ousting of the British in 1952.50 Egypt's flag - in fact, known as the Liberation Flag - similarly got its name and came into existence around the same time and was prominently featured in Tahrir festivities shortly after the 1952 Revolution. ${ }^{51}$ Already symbolizing values of liberty and national unity at the outset of Egypt's 2011 Arab Spring, the square and flag were seized as revolt symbols of solidarity against the military dictatorship of Hosni Mubarak. ${ }^{52}$ Thus, both were semantically imbued with revolutionary meaning that readied them for protest, ${ }^{53}$ and the square's significance was further accentuated by the syntax of the space. "Syntax" here refers to rhythms of human movement and contact ${ }^{54}$ that coalesced in Tahrir because it is a hub for major streets, the metro system, prominent buildings and the Qasr El Nil Bridge, a landmark connecting downtown Cairo to Zamalek Island, an affluent and trendy area. This made the square a natural place for protest. In the summer of 2013, however, the military leadership reabsorbed Tahrir and the flag - which were at this point symbols of defiance - to fuel dissent against the elected Islamist government. They did so by dropping flags from helicopters into protesting masses in Tahrir, for example. ${ }^{55}$ More recently, authorities have placed an austere, massive pedestal with an Egyptian flag in the center of Tahrir Square. This is in addition to

44 Gibson, The Ecological Approach to Visual Perception, 140.

45 Ibid., 140.

46 For example, Maier et al., "An affordance-based approach to architectural theory, design, and practice;” Marcus, "Overcoming the Subject-Object Dichotomy in Urban Modeling: Axial Maps as Geometric Representations of Affordances in the Built Environment;” Uzzell, “The Socio-Environmental Affordances of Adolescents' Environments;” Rivlin, "Found Spaces: Freedom of Choice in Public Life.”

47 Crippen, "Group Cognition in Pragmatism, Developmental Psychology and Aesthetics;" Crippen and Schulkin, Mind Ecologies: Body, Brain, and World; Krueger, "Extended Cognition and the Space of Social Interaction;" Still and Good, "The Ontology of Mutualism."

48 See Klement, "Moral and Political Implications of Urbanism," Ch. 6. For a normative account of affordances, albeit one not focused on ethics, politics or urban life, see Hufendiek's "Affordances and the Normativity of Emotions."

49 "Babies of the Borough - using behavioural insights to reduce anti-social behavior," https://www.local.gov.uk/babiesborough-using-behavioural-insights-reduce-anti-social-behaviour.

50 Gardener, The road to Tahrir Square: Egypt and the United States from the Rise of Nasser to the fall of Mubarak.

51 Podeh, The Politics of National Celebrations in the Arab Middle East.

52 Crippen, "Contours of Cairo Revolt."

53 Ibid.

54 For review, see Vaughan, "The Spatial Syntax of Urban Segregation.”

55 Crippen, “Asleep at the Press: Thoreau, Egyptian Revolt and Nuances of Democracy;” Crippen, “Contours of Cairo Revolt.” 
introducing design features in line with Newman's defensible space model that psychologically repel entry. ${ }^{56}$

Though one can question whether planners read Newman's work, the redesign indicates familiarity with the principles of implicit social control that he advocated, along with the general crime prevention through environmental design (CPTED) that his research augured. In fact, the square was little more than a poorly maintained roundabout shortly before the January 2011 Revolution. However, planners transformed it into a textbook case of Newman's defensible space model in the period after the 2013 military coup of elected Islamists.

A low, ornamental wall was added around the square, marking the territory as semiprivate in the same way picket fences do. In line with Neman's call to limit access points, entrances in the wall were restricted to three, with one of them bricked over. The wall encircled a well-kept lawn with decorative shrubs, furthering the appearance of entering into a privately maintained and hence controlled space. The impression was more powerful in the Egyptian context where entry to manicured areas often requires payment or passing security checkpoints to enter gated communities. Moving closer to the middle, one encountered another decorative wall that encloses the middle hub, again with three access points. A slightly elevated area surfaced with masonry of a different color - this time gray - further distinguished the central ring from the rest of the square. At the middle was yet another raised portion, followed by the austere pedestal with the flag. Though seemingly innocuous, small gestures such as a little extra elevation have been empirically shown to repel entry, ${ }^{57}$ and Tahrir Square augmented this by virtue of having the air of a mausoleum - even more so in a cultural context where dead protesters are called "martyrs." While the square remained physically accessible, the defensible features generated a feeling of entering a restricted space, especially in the threatening political climate of today. With all of these changes in play, and police around to make people feel uncomfortable, the square fell into vacancy most of the time. This was out of place in Egypt, where people characteristically occupy even grassy medians in busy roads because parks typically impose fees. Emptiness, moreover, tends to be self-feeding since a paucity of people is less attractive to others and signals that an area is forbidden. ${ }^{58}$

The postcoup alterations of Tahrir Square - which was refashioned into a more neutral space in 2020 - accordingly shrunk political affordances for both physical and ideological engagement. The word "affordance" here applies because psychological variants of hostile design extinguished openings for action. In addition to this, the introduction of hostile features and the erection of the flag signaled an end to political dialogue. Inscribed almost as plainly as words, yet registered prereflectively, this physical-cultural space now delivered a stark message: "The revolution is over, and we won." "We" stands for the military, and weakly for the people. This is because the military has branded itself as serving the people, while in practice being a subjugating force. In gestural language, then, the redesign was basically a middle-finger salute. It conveyed an ominous message: "Retreat from this space and especially the ideology it represents, or suffer severe penalties." Thus, the redesign of the square symbolically expressed and suppressed values in an attempt to fully reclaim and hence contain the idea of Tahrir and the January Revolution.

This reiterates Gibson's suggestion that affordances show up as values, even though he was not referring to political contexts when making the point. After the pedestal and flag were raised, the space took on an austere, almost sacred vibe, like a war memorial. Furthermore, the partial cordoning of the square and other design features exactly mirrors the curbs, decorative fences and pathways that Newman advocates and had just the effect he desires: it makes the space feel prohibited. This is more so in a context in which people feel surveilled, with some disappearing or arbitrarily detained. ${ }^{59}$

\footnotetext{
56 "Contours of Cairo Revolt."

57 Whyte, The Social Life of Small Urban Spaces, 58.

58 Jacobs, The Death and Life of Great American Cities; Whyte, The Social Life of Small Urban Spaces.

59 Crippen, "Egypt and the Middle East: Democracy, Anti-Democracy and Pragmatic Faith."
} 
The psychologically hostile redesign of Tahrir accordingly indicated both the area and the revolutionary ideals were - to requote Newman - "under the undisputed influence of a particular group," ${ }^{60}$ in this case, the military regime. The depressed mood in Egypt arguably enhanced Tahrir's hostility, and this fits Gibson's theory of affordances. His account is grounded in the pragmatic and phenomenological notion, to put it in John Dewey's phraseology, that subject and object - agent and environment - are built up and completed in one and the same operation. ${ }^{61}$ Thus, water shows up as walkable to certain insects and less so to humans because it in fact has these properties relative to the respective capacities of these different organisms. ${ }^{62}$ Mood corresponds to energy levels, hence objective capacities for action relative to environments, and experiments on affordances indicate that fatigue and sadness make inclines appear further away and steeper. ${ }^{63}$ This means less approachable and climbable and therefore less accessible, with people accordingly less apt to explore. On the premise that Newman's tacit territory markers are a variety of affordance, it is plausible that defensive barriers are more severe to Egyptians. This is because the bad political situation has weakened an already difficult economy, with this dual hardship draining energy from Egyptians. It does not help that the politically active and the nonpolitical are both at risk since arbitrary imprisonment occurs. ${ }^{64}$ In cities less overrun by malaise and fear, by contrast, a square with identical features to postcoup Tahrir might invite approach and exploration. However, affairs are not so in Egypt where people feel surveilled and experience a vague but genuine threat looming in the background.

In the emotional environs of Egypt, therefore, the cordoned square, flag and austere pedestal were antagonistic to approach. They closed Tahrir as a political affordance, limiting people's ability to act and see beyond the current order. Paraphrasing Gestalt psychologists, Gibson hints that emotional, affective or valuative tones moderate how we perceive and cognitively grasp spaces, as when we register an area as safe or dangerous, perhaps moving forward or retreating. All this together helps us perceive and categorize "each thing," telling us "what it is" and "what to do" with it, as Gibson writes. ${ }^{65}$ Though ethical and political connotations are unintended by Gibson, his phraseology has normative tones. Gibson's scheme, moreover, is unequivocally valuative. He maintains that "benefits and injuries" and "safeties and dangers," in short, "positive and negative affordances" are all "properties of things taken with reference to an observer but not properties of the experiences of the observer. They are not subjective values." ${ }^{66}$ For Gibson, this "implies that the 'values' and 'meanings' of things in the environment can be directly perceived. Moreover, it would explain the sense in which values and meanings are external to the perceiver." ${ }^{\prime 67}$

The same can be said of political affordances: that they are not subjective, but nonetheless relative to the ease or difficulty with which people can act in certain cultural environments. This means a square with exactly the same parameters as Tahrir might be inviting in an alternative cultural environment; likewise, in the same cultural environment, tourists not suffering diminished capacities due to political and economic affairs might regard it as a welcoming space. The relative nature of how things show up does not, however, make political affordances merely subjective: they are real and extant in the urban ecology, which includes the physical layout, things in it and people too. Gibson writes that a cliff "affords falling

60 Newman, Defensible Space, 3.

61 Dewey, Art as Experience, 177; Merleau-Ponty, Phenomenology of Perception; also see Crippen, "Body Phenomenology, Somaesthetics and Nietzschean Themes in Medieval Art;" Crippen, "Dewey, Enactivism and Greek Thought;" Hoel and Carusiz, "Merleau-Ponty and the Measuring Body."

62 Crippen "Aesthetics and Action," Section 5.

63 See Bhalla and Proffitt, "Visual-Motor Recalibration in Geographical Slant Perception;” Proffitt, "Embodied Perception and the Economy of Action;” Riener et al., "An Effect of Mood on the Perception of Geographical Slant.” Schnall et al., "Direct Evidence for the Economy of Actions: Glucose and the Perception of Geographical Slant;" Zadra et al., "Direct physiological evidence for the economy of action: Bioenergetics and the perception of spatial layout."

64 Crippen, "Egypt and the Middle East;" Shenker, The Egyptians: A Radical Story.

65 Gibson, The Ecological Approach to Visual Perception, 38; also see Crippen, "Embodied Cognition and Perception: Dewey, Science and Skepticism."

66 Gibson, The Ecological Approach to Visual Perception, 137.

67 Ibid., 127. 
off" and "looks dangerous" and "is in fact dangerous" to humans. ${ }^{68}$ For Egyptians, the square looks threatening because it is threatening to them and less so to tourists who tend to see it as less forbidding. In Gibsonian-Gestalt terms, the space tells Egyptians "what to do" with it, in this case, nothing. The square is to be avoided, and this is - to repeat-because it is marked as under the undisputed control of the military regime. Gibson was influenced by pragmatists, ${ }^{69}$ and on the pragmatic premise that willingness to act measures the strength of belief, ${ }^{70}$ one worries about the norms of the military government becoming increasingly acceptable as people see fewer avenues for resistance.

\section{Selective permeability}

A key point to consider in hostile arrangements is not only that they repel entry but that they selectively filter people. Defensible space does this most obviously by exerting ownership and psychologically repelling outsiders. The Tahrir example further highlights that architecture can filter according to personal situation. In the case of Tahrir, the general malaise of Egyptians arguably makes them more susceptible to defensible measures. In other spaces ordered along Newman's lines, the same applies - for example, with the homeless arguably more susceptible to hostile affordances than the affluent. This is because one would expect the homeless to suffer lower mood, energy and blood sugar, which all correlate with affordances looking more strenuous. ${ }^{71}$ On grounds already argued, the impoverished should therefore see greater severity in Newman's latent boundaries, ${ }^{72}$ which we have variously framed as symbolic or political affordances.

These views align with postphenomenology. This is an approach to technology drawing on classical phenomenology and pragmatism, ${ }^{73}$ while avoiding the overly encompassing proclamations typical of the most famous phenomenologist, Martin Heidegger. ${ }^{74}$ Approximating the notion of selective permeability, postphenomenologists advance the concept of multistability: the idea that the same object - and we can add the same space - shows up differently and is in fact different to various people. ${ }^{75}$ The precept is found in Gibson's work, which points out that rocks may variously be used as pendulum bobs, hammers or missiles. ${ }^{76}$ It appears earlier still in the pragmatic work of William James, which influenced Gibson and argues that interests and practical dispositions affect how things manifest, as when a carpenter regards oil as a wood darkener, while a mechanic conceives of it as a lubricant. ${ }^{77}$ Fellow pragmatists Dewey expresses the idea in embodied terms when he writes that things and their properties "are what they can do and what can be done with them."78 Dewey thereby anticipates the phenomenologist Maurice Merleau-Ponty

68 Ibid., 142.

69 Ibid., Preface; also see Chemero and Käufer. “Pragmatism, Phenomenology, and Extended Cognition;” Reed, James J. Gibson and the Psychology of Perception.

70 James, “Rationality, Activity and Faith,” 458; James, “The Will to Believe,” 458; also see Crippen, "William James on Belief: Turning Darwinism Against Empiricistic Skepticism.”

71 Bhalla and Proffitt, "Visual-Motor Recalibration in Geographical Slant Perception;” Proffitt, "Embodied Perception and the Economy of Action;” Riener et al., “An Effect of Mood on the Perception of Geographical Slant.” Schnall et al., "Direct Evidence for the Economy of Actions: Glucose and the Perception of Geographical Slant;" Zadra et al., "Direct physiological evidence for the economy of action: Bioenergetics and the perception of spatial layout."

72 Crippen, “A Tale of Two or Three Cities.”

73 Aagaard, "Magnetic and Multistable: Reinterpreting the Affordances of Educational Technology."

74 Ibid.

75 See Hasse, An Anthropology of Learning: On Nested Frictions in Cultural Ecologies; Ihde, Technology and the Lifeworld: From Garden to Earth; Rosenberger, "Why It Takes Both Postphenomenology and STS."

76 Gibson, The Ecological Approach to Visual Perception, 134.

77 James, "The Sentiment of Rationality;" also see Crippen, "Pragmatic Evolutions of the Kantian a priori: From the Mental to the Bodily."

78 Dewey, Reconstruction in Philosophy, 115; also see Crippen, “Art and Pragmatism: James and Dewey on the Reconstructive Presuppositions of Experience.” 
and the pragmatist George Herbert Mead. He makes the just quoted statement in reference to a carpenter deploying tools to work with wood, and Don Ihde - a major figure in postphenomenology - repeats the claim almost verbatim. ${ }^{79}$

Pulling these threads together, and noting Gibson's overzealous attempt to differentiate himself from his Gestalt predecessors who maintain that things have "demand characters" that vary with temporary interests, ${ }^{80}$ Jesper Aagaard - another postphenomenological theorist-argues that affordances are not neutral avenues for action: that the same affordance can have magnetic appeal for one person and not another, as when students are differentially distracted by openings for social engagement on mobile devices. The idea of selectively permeable design posits roughly the same, but somewhat in reverse. Instead of differential magnetic pull, urban spaces repulse differentially, with distinct modes of engagement depending on the particular situations of individuals and related action-capacities. This happens with Newman's implicit boundaries and with the political affordances of Tahrir, which, for theoretical reasons already explained, are more severe for those worn out by life, whether through physical malady or social oppression. This implies different normative meanings in urban space, so that an area communicates that it is forbidden as clearly as written signs do but only to select groups. These arrangements amount, therefore, to a kind of invisible social warfare, with the nonoppressed largely blind to the weight that urban form imposes on subjugated groups.

Social warfare abounds in urban space. One such case is a high-pitched sound known as the Mosquito because of its resemblance to the buzz produced by that species. ${ }^{81}$ Its frequency is usually set in the $17.5-18.5 \mathrm{kHz}$ range, typically only audible to people under 25 years..$^{82}$ Individuals in this age category not only hear this ultrasonic sound, but they find it annoying, even painful, yet only vaguely identifying the source of irritation since the Mosquito "produces an abstract sound that has no referent." Due to its "lack of referentiality, the sound of the Mosquito almost seems sourceless, as though the noise is coming from within one's own head." 83 Youths report feeling headaches-almost the sensation of a swelling brain - and other varieties of discomfort. ${ }^{84}$ There is even some indication that the Mosquito produces nausea and disequilibrium, perhaps damaging hearing too. ${ }^{85}$ The Mosquito might be seen as an evolution of earlier measures for selectively repulsing youth such as Muzak and other forms of easy listening disliked by teens, ${ }^{86}$ but it is more extreme than this. It approaches techniques employed by United States military and intelligence personnel, specifically the use of loud music - for instance, country-western, rock or metal - to break prisoners or enemies. ${ }^{87}$ The commonality is that the Mosquito inflicts pain, regulating locales through quasi-military measures..$^{88}$ In this way, the device selectively manages behavior of those susceptible to it. This parallels the military reorganization of Tahrir Square, which exerts implicit control over human movement, not to mention longer term political thought and action. Only the Mosquito regulates commercial space, and it is now implemented in shopping malls, street corners and other places where youths are unwanted.

A similar - albeit less aggressive - example is pink lighting, which increases the visibility of facial blemishes common in young adults. ${ }^{89}$ Feeling unattractive and perhaps humiliated when in these pink-lit

79 Ihde, Technology and the Lifeworld.

80 For example, Koffka, Principles of Gestalt Psychology.

81 Akiyama, "Silent Alarm;" Klement, "Moral and Political Implications of Urbanism;" Petty, "The London Spikes Controversy."

82 Akiyama, "Silent Alarm;” Klement, "Moral and Political Implications of Urbanism.”

83 Akiyama, "Silent Alarm," 461.

84 Akiyama, "Silent Alarm," 463; Klement, "Moral and Political Implications of Urbanism."

85 German Federal Institute for Occupational Safety and Health, "Einsatz von Ultraschall-Störgeräusch-Sendern nicht ganz unbedenklich;" Fletcher et al., "Effects of very High-Frequency Sound and Ultrasound on Humans."

86 Cusick, "Music as torture/Music as weapon;" Hirsch, Weaponizing Classical Music: Crime Prevention and Symbolic Power in the Age of Repetition;" Sterne, "Urban Media and the Politics of Sound Space."

87 Cusick, "Music as Torture/Music as Weapon."

88 Akiyama, "Silent Alarm."

89 Klement, "Moral and Political Implications of Urbanism;" Petty, “The London Spikes Controversy.” 
areas, youths are less inclined to loiter. Put otherwise, places become unappealing because they make people feel unappealing. Instigated in Mansfield and other United Kingdom cities, pink light corrals youths out of certain areas - particularly ones hosting businesses operated by managers desiring teen-free spaces. ${ }^{90}$ Insofar as this lowers self-esteem and hence mood, pink lighting may have the additional effect of selectively making teens more susceptible to latent markers of territory in Newman's vein, excluding them in this way too. ${ }^{91}$ The Mosquito may be similar insofar as constant irritation and physical pain are fatiguing, with exhaustion making exclusionary affordances - or implicit territory indicators - show up more forcefully. By this reasoning, one can speculate that latent territory becomes more severe to youths. Notice, moreover, that all of these regulating effects likely occur with minimal awareness, with youths simply finding themselves not dwelling in areas bathed in pink light or subject to the Mosquito hum. Much the same holds for people who find themselves prereflectively nudged out of spaces by Newman's defensive measures without fully registering why.

The Mosquito and pink light accordingly parallel the reconstruction of Tahrir Square, which was a psychological variation in hostile design such as spikes on low-lying decorative walls or arms on benches or sprinkler systems in parks intended to prevent sitting or sleeping. From the standpoint of Egyptians - as opposed, say, to tourists - the postcoup square exists in a climate of fear: Egyptians are depressed; their protest slogan was "bread, freedom, social justice and human dignity," ${ }^{92}$ and demonstrators fought hard to achieve this; they won a brief victory against odds, only to have it all taken away again. ${ }^{93}$ With the population now worn out, defensible measures look much more forbidding - or so we have argued. Insofar as the square selectively filtered the politically fatigued, and similar measures in less threatening places might exclude, say, exhausted homeless; and inasmuch as the Mosquito and pink light ostracize youth, all stand as psychological variants of Robert Moses's low overpasses intended to selectively impede bus transportation from poor and especially black neighborhoods to Jones Beach. ${ }^{94}$

It is worth reemphasizing that selectively hostile and thus multistable design features are largely invisible to those unsusceptible to them and often also to those who are being manipulated. To most people, sprinklers just keep parks lush; yet they become explicit obstacles to homeless wishing to rest in green areas at night, who are nonetheless unlikely to discern that the timing of watering is targeted to drive them out. Something similar holds for antiskateboarding features: skateboard enthusiasts cannot help but see them, whereas almost everyone else does not know they are there. The Mosquito and pink light are perhaps subtler insofar as they implicitly influence youths: their behavior is regulated, but few of them appreciate why. At the same time, these measures are mostly or entirely nonexistent for older individuals who therefore fail to see them as problematic. The action- and ideology-closing adjustments introduced to Tahir also corralled behavior on an implicit level, which is to say, it is doubtful that many Egyptians identified how the redesign influenced them. Simultaneously and somewhat paradoxically, the addition of defensible measures sent an unmistakable message to Egyptians who unequivocally realized that the space and its ideology were to be avoided, almost as clearly as if "Keep Out" signs were posted. For the majority of tourists, by contrast, the political affordances of Tahrir were nonexistent. This is because most tourists do not have deep familiarity with the social context, nor face the same objective threats as Egyptians. Thus, as Mike Davis sums up "The totalitarian semiotics of ramparts and battlements, reflective glass and elevated pedways, rebukes any affinity or sympathy between different architectural or human orders." He adds "This is the archisemiotics of class war." 95

90 Klement, "Moral and Political Implications of Urbanism."

91 While attending to different cases, Smith and Walters offer a similar analysis in "Desire Lines and Defensive Architecture." 92 Pleyers and Glasius, “The Movements of 2011: Democracy, Social Justice, Dignity;" Teti and Gervasio, "The Unbearable Lightness of Authoritarianism: Lessons from the Arab Uprisings.”

93 For example, Crippen, "Egypt and the Middle East."

94 See Caro, The Power Broker: Robert Moses and the Fall of New York; Winner, "Do Artifacts have Politics?" 95 Davis, City of Quartz: Excavating the Future in Los Angeles, 231. 


\section{Conclusion}

In this article, we started by examining how normative values are embedded in urban space. We particularly focused on architecture emphasizing soldierly values of defensibility by implicitly delineating private space, comparing these traits to standard hostile features such as spiked surfaces and sprinkler systems intended to prevent homeless people from sleeping. We went on to conceptualize these latent markers as symbolic affordances, arguing that people encounter them in the same way as physical obstacles: when confronting a picket fence, we act as if it is an impassable perimeter. We then introduced the notion of political affordances. This captures the fact that implicit boundaries and physical obstacles corral human movement, consequently opening or closing avenues for political action, which links reciprocally with normative visions. We finally connected political affordances to selectively permeable design that filters people according to parameters such as age, fatigue level and socioeconomic status, framing this within broader notions of multistability advanced in postphenomenological circles.

By introducing Gibson's ecological psychology - and by extension pragmatic and phenomenological thought influencing him ${ }^{96}$ - we also tacitly suggested refinements to ethical epistemologies. Our views in some ways approach Jesse Prinz's account of morality, albeit departing from his subjectivism. On his account, holding a moral judgment entails feeling an emotional (sentimental) response in one's body. Prinz further maintains that morality is culturally conditioned. ${ }^{97}$ His framework accordingly implies there is no universally true morality. Prinz more specifically proposes that an "action has the property of being morally wrong (right) just in case there is an observer who has a sentiment of disapprobation (approbation) toward it." 98 Cities obviously shape the affective lives of their inhabitants, and a pertinent question is whether this cultivates normative visions too. We suggested something like this on the grounds that design manifests values that shape actions; it also generates actions that make values show up in ways described by Gibson. ${ }^{99}$ A trivial example is that many feel they are doing something wrong if they cross a decorative fence to enter a grassy courtyard in a university commons. Even if they do not reach this assessment, most find themselves respecting the tacitly marked perimeter and hence the normative value embedded in the design, even when there are no signs forbidding access or other explicit reasons not to go on the grass.

With pragmatists and phenomenologists such as Dewey, Mead, Heidegger and Merleau-Ponty, ${ }^{100}$ Gibson departs from Prinz by spurning his emphasis on mental representations and his clunky language sharply dividing stimulus, cognition, emotion and response. More generally, Gibson sees little need to tell stories about what is occurring inside our heads and thereby avoids the subjectivism that plagues the majority of thinking on mind from the early Modern period onward. But there are significant commonalities between recent evolutions of Gibsonian psychology and some of Prinz's current views on mind. ${ }^{101}$ Not surprisingly, then, there are also similarities between their renderings of values. They both hold that psychological and cultural conditions affect how things show up. However, research on affordances adds that psychological conditions affect how things appear by altering the possibilities of action in the world, as when depression lowers energy and thus capacity to move forward. In Gibson's scheme, this means values can alter under similar circumstances; there is no unequivocal distinction between acting in physical and cultural environments; cultural factors also moderate capacities to act, hence affordances and values; and from a Gibsonian standpoint, all of this is in ecological relations and

96 See Chemero and Käufer, "Pragmatism, Phenomenology, and Extended Cognition;" Reed, James J. Gibson and the Psychology of Perception.

97 Prinz, Emotional Construction of Morals.

98 Ibid., 9.

99 Aydin, Woge and Verbeek make a comparable claim when they suggest that actions generate intentions in their "Technological Environmentality: Conceptualizing Technology as a Mediating Milieu."

100 Dewey, Art as Experience; Heidegger, Being and Time; Mead, The Philosophy of the Act; Merleau-Ponty, Phenomenology of Perception.

101 See Shargel and Prinz, "An Enactivist Theory of Emotional Content.” 
not just in our heads. To repeat Gibson's example, a cliff-edge affords falling; it looks dangerous and is in fact so to humans, and it is characteristically perceived as having emotionally threatening values, even if one is currently not at risk. This is just as Tahrir Square looks comparatively more dangerous to most politically exhausted Egyptians and is indeed more dangerous to them than to tourists since police avoid hassling the latter. This points to a framework for undermining the notion that values are merely subjective.

An additional theme repeated throughout this article is that urban form is psychologically fragmented, that is, designed to regulate behavior in ways upholding neoliberal values where nearly everything is for sale and subject to private control. Design increasingly determines who gets in or stays out, whether by driving youth away with humiliating pink light, by deploying quasi-violent ultrasonic sound or by filtering those worn out by life with implicit signs of ownership. Much of this is done at the behest of business interests. This very much includes the Egyptian government, where army conscripts provide cheap labor in privately owned factories ${ }^{102}$ and where the country has generally adopted neoliberal policies favoring the ruling classes. ${ }^{103}$ Taken together, these tendencies reflect a growing trend to simply equate the moral and political good to demands of commercialism. ${ }^{104} \mathrm{~A}$ familiar example is the cash valuing of education and the near abandonment of pursuing it as a final end. In other words, the ideal that it is worth developing oneself like a work of art is no longer taken seriously and further rooted out by financial exigencies placed on young adults. We earlier asked whether city design influences moral values and have answered in the affirmative. However, articulating just how this plays out is challenging because it is difficult to parse the causes from symptoms, and many of the ills we have identified are surely both.

Acknowledgments: We are grateful to the guest editor Sanna Lehtinen and the three reviewers for their very helpful suggestions. We would also like to thank the Philosophy of the City group for providing a supportive environment to test ideas in this article and numerous past publications.

\section{References}

Aagaard, Jesper. "Magnetic and Multistable: Reinterpreting the Affordances of Educational Technology." International Journal of Educational Technology in Higher Education 15 (2018), 1-10. doi: 10.1186/s41239-017-0088-4.

Akiyama, Mitchell. "Silent Alarm: The Mosquito Youth Deterrent and the Politics of Frequency." Canadian Journal of Communication 35 (2010), 455-71.

Aydin, Ciano, Woge, González Margoth, and Verbeek, Peter-Paul. “Technological Environmentality: Conceptualizing

Technology as a Mediating Milieu.” Philosophy and Technology 32 (2019), 321-38.

Bacon, Edmund N. Design of Cities. New York: Penguin Books, 1967.

Bhalla, Mukul, and Proffitt, Dennis R. "Visual-Motor Recalibration in Geographical Slant Perception.” Journal of Experimental Psychology: Human Perception and Performance 25 (1999), 1076-96.

Boukhari, Jamal. “Egypt's Conscripts Serving the Army's Economic Empire.” The New Arab, September 5, 2017. https://english. alaraby.co.uk/english/Comment/2017/9/5/Egypts-conscripts-serving-the-armys-economic-empire.

Caro, Robert A. The Power Broker: Robert Moses and the Fall of New York. New York: Knopf, 1974.

Chellew, Cara. "Defending Suburbia: Exploring the Use of Defensive Urban Design Outside of the City Centre." Canadian Journal of Urban Research 28 (2019), 19-33.

Chemero, Anthony, and Käufer, Stephan. "Pragmatism, Phenomenology, and Extended Cognition.” In Pragmatism and Embodied Cognitive Science: From Bodily Interaction to Symbolic Articulation, edited by R. Madzia, M. Jung, 55-70. Berlin: De Gruyter, 2016.

102 Boukhari, "Egypt's Conscripts Serving the Army’s Economic Empire;” Tadros, "Egypt Military’s Economic Empire.” 103 Shenker, The Egyptians.

104 Sagoff, “At the Shrine of Our Lady of Fatima or Why Political Questions Are Not All Economic.” Frankfurt theorists make comparable arguments as Sagoff. See Crippen, "The Totalitarianism of Therapeutic Philosophy: Reading Wittgenstein Through Critical Theory." 
Clark, Charlotte, and Uzzell, David L. "The Socio-Environmental Affordances of Adolescents Environments." In Children and Their Environments, edited by Christopher Spencer and Mark Blades, 176-96. New York: Cambridge University Press, 2006.

Crippen, Matthew. "The Totalitarianism of Therapeutic Philosophy: Reading Wittgenstein Through Critical Theory." Essays in Philosophy 8 (2007), 29-55.

Crippen, Matthew. "William James on Belief: Turning Darwinism Against Empiricistic Skepticism." Transactions of the Charles S. Peirce Society 46 (2010), 477-502.

Crippen, Matthew. “Art and Pragmatism: James and Dewey on the Reconstructive Presuppositions of Experience.” PhD dissertation. York University, 2010.

Crippen, Matthew. "Body Phenomenology, Somaesthetics and Nietzschean Themes in Medieval Art." Pragmatism Today 5 (2014), 40-5.

Crippen, Matthew. “Asleep at the Press: Thoreau, Egyptian Revolt and Nuances of Democracy.” Arab Media and Society, 20 (2015), 1-14. https://www.arabmediasociety.com/wp-content/uploads/2017/12/20150302085925_Crippen_ AsleepAtThePress.pdf.

Crippen, Matthew. “Dewey, Enactivism and Greek Thought.” In Pragmatism and Embodied Cognitive Science: Bodily Interaction to Symbolic Articulation, edited by Roman Madzia, Matthias Jung, 229-46. Berlin: De Gruyter, 2016.

Crippen, Matthew. “Egypt and the Middle East: Democracy, Anti-Democracy and Pragmatic Faith." Saint Louis University Public Law Review 35 (2016), 281-302.

Crippen, Matthew. "Intuitive Cities: Pre-reflective, Aesthetic and Political Aspects of Urban Design." Journal of Aesthetics and Phenomenology 3 (2016), 125-45.

Crippen, Matthew. "Embodied Cognition and Perception: Dewey, Science and Skepticism." Contemporary Pragmatism 14 (2017), 121-34.

Crippen, Matthew. “Group Cognition, Developmental Psychology and Aesthetics.” Pragmatism Today 8: 2017, $185-97$.

Crippen, Matthew. "Pragmatism and the Valuative Mind." Transactions of the Charles S. Peirce Society 54 (2018), 341-60.

Crippen, Matthew, "Aesthetics and Action: Situations, Emotional Perception and the Kuleshov Effect." Synthese [issue unassigned] (2019). doi: 10.1007/s11229-019-02110-2.

Crippen, Matthew. "Body Politics: Revolt and City Celebration." In Bodies in the Streets: Somaesthetics of City Life, edited by R. Shusterman, 89-110. Boston: Brill, 2019.

Crippen, Matthew. "Contours of Cairo Revolt: Semiology and Political Affordances in Street Discourses." Topoi [issue unassigned] (2019). doi: 10.1007/s11245-019-09650-9.

Crippen, Matthew. "Pragmatic Evolutions of the Kantian a priori: From the Mental to the Bodily." In Pragmatist Kant: Pragmatism, Kant, and Kantianism in the Twenty-First Century, edited by Krzysztof Piotr Skowroński, Sami Pihlström, 19-40. Helsinki: Nordic Pragmatism Network, 2019.

Crippen, Matthew. “A Tale of Two or Three Cities." Paper presented at Philosophy of the City, University of Detroit Mercy, Detroit, MI, October 5, 2019.

Crippen, Matthew and Schulkin, Jay. Mind Ecologies: Body, Brain, and World. New York: Columbia University Press, 2020.

Cusick, Suzanne. “Music as Torture/Music as Weapon.” Transcultural Music Review 10 (2006), 3. http://www.sibetrans.com/ trans/articulo/152/music-as-torture-music-as-weapon.

Damasio, Antonio. Descartes' Error: Emotion, Reason, and the Human Brain. New York: G. P. Putnam, 1994.

Davis, Mike. City of Quartz: Excavating the Future in Los Angeles. London: Verso, 2018.

Dewey, John. Reconstruction in Philosophy. New York: Henry Holt, 1920.

Dewey, John. Art as Experience. New York: Minton, Balch, 1934.

Fletcher, Mark D., Jones, Sian Lloyd, White, Paul R., Dolder, Craig N., Leighton, Timothy G., and Lineton, Benjamin. "Effects of Very High-Frequency Sound and Ultrasound on Humans. Part I: Adverse Symptoms after Exposure to Audible Very-High Frequency Sound." The Journal of the Acoustical Society of America 144 (2018), 2511-20.

Foucault, Michel. Discipline and Punish: The Birth of the Prison. Trans. Alan Sheridan. New York: Vintage Books, 1995. First printed in French in 1975.

Friedman, Batya, Khan, Peter H., and Borning, Alan. "Value Sensitive Design and Information Systems." In The Handbook of Information and Computer Ethics, edited by Kenneth E. Himma and Herman T. Tavani, 69-101. Hoboken, NJ: John Wiley and Sons, 2018.

Gibson, James J. The Ecological Approach to Visual Perception. Boston: Houghton-Mifflin, 1979.

Gardener, Lloyd C. The Road to Tahrir Square: Egypt and the United States from the Rise of Nasser to the Fall of Mubarak. New York: Saqi, 2011.

German Federal Institute for Occupational Safety and Health. "Einsatz von Ultraschall-Störgeräusch-Sendern nicht ganz unbedenklich,” December 4, 2007. https://web.archive.org/web/20110927131822/http://www.baua.de/nn_5858/de/ Presse/Pressemitteilungen/2007/12/pm079-07.html.

Hasse, Cathrine. An Anthropology of Learning: On Nested Frictions in Cultural Ecologies. New York: Springer, 2015.

Heidegger, Martin. Being and Time, 1927. Trans. J. Macquarrie and E. Robinson. New York: Harper and Row, 1962. First printed in German in 1927. 
Hirsch, Lily E. "Weaponizing Classical Music: Crime Prevention and Symbolic Power in the Age of Repetition." Popular Music Studies 19 (2007), 342-58.

Hoel, Aud Sissel, and Carusiz, Annamaria. "Merleau-Ponty and the Measuring Body." Theory, Culture and Society 35 (2017), 45-70.

Hufendiek, Rebekka. "Affordances and the Normativity of Emotions." Synthese 194 (2017), 4455-76.

Ihde, Don. Technology and the Lifeworld: From Garden to Earth. Indianapolis: Indiana University Press, 1990.

Ihde, Don. "Introduction: Postphenomenological Research." Human Studies 31 (2008), 1-9.

Jacobs, Jane. The Death and Life of Great American Cities. New York: Vintage, 1961.

James, William. "Rationality, Activity and Faith." Princeton Review 2 (1882), 58-86.

James, William. "The Sentiment of Rationality." 1879. In William James: Writings 1878-1899, edited by G. E. Myers, 950-85. New York: Library of America, 1992.

James, William. “The Will to Believe.” 1896. In William James: Writings, 1878-1899, edited by G. E. Myers, 457-79. New York: Library of America, 1992.

Joerges, Bernward. “Do Politics Have Artefacts?” Social Studies of Science 29 (1999), 411-31.

Johnson, Mark. The Aesthetics of Meaning and Thought: The Bodily Roots of Philosophy, Science, Morality, and Art. Chicago: University of Chicago Press, 2018.

Kaplan, Rachel, and Kaplan, Stephen. The Experience of Nature: A Psychological Perspective. New York: Cambridge University Press, 1989.

Katyal, Neal Kumar. “Architecture as Crime Control.” Yale Law Journal 111 (2002), 1039-139.

Klement, Vladan. "Tools for Shaping Human Behavior in Public Spaces: Theory and Praxis." Paper presented at Philosophy of the City, University of Detroit Mercy, Detroit, MI, October 5, 2019.

Klement, Vladan. "Moral and Political Implications of Urbanism." PhD diss., Masaryk University, 2020.

Knoblauch, Joy. "The Economy of Fear: Oscar Newman Launches Crime Prevention through Urban Design (1969-197x)." Architectural Theory Review 19 (2014), 336-54.

Koffka, Kurt. Principles of Gestalt Psychology. New York: Harcourt, Brace and Company, 1935.

Krueger, Joel. "Extended Cognition and the Space of Social Interaction." Consciousness and Cognition 20 (2011), 643-55.

Local Government Association. "Babies of the Borough - Using Behavioural Insights to Reduce Anti-Social Behaviour." Communities: Efficiency and Income Generation, November 29, 2017. https://www.local.gov.uk/babies-borough-using behavioural-insights-reduce-anti-social-behaviour.

Maier, Jonathan R. A., Fadel, Georges, and Battisto, Dina G. "An Affordance-based Approach to Architectural Theory, Design, and Practice." Design Studies 30 (2009), 393-414.

Marcus, Lars. "Overcoming the Subject-Object Dichotomy in Urban Modeling: Axial Maps as Geometric Representations of Affordances in the Built Environment." Frontiers in Psychology, 9 (2018). doi: 10.3389/fpsyg.2018.00449.

Mead, George Herbert. In The Philosophy of the Act, edited by Charles W. Morris, John M. Brewster, Albert M. Dunham, David Miller. Chicago: University of Chicago, 1938.

Merleau-Ponty, Maurice. Phenomenology of Perception. Trans. Collin Smith. New York: Routledge and Kegan Paul, 1962. First printed in French in 1945.

Németh, Jeremy. “Conflict, Exclusion, Relocation: Skateboarding and Public Space.” Journal of Urban Design 11 (2006), 297-318.

Newman, Oscar. Creating Defensible Space. Washington, DC: Department of Housing and Urban Development, Office of Policy Development and Research, 1996.

Newman, Oscar. Defensible Space: Crime Prevention through Urban Design. New York: Macmillan, 1972.

Petty, James. "The London Spikes Controversy: Homelessness, Urban Securitisation and the Question of 'Hostile Architecture'." International Journal for Crime, Justice and Social Democracy 5 (2016), 67-81.

Pleyers, Marlies, and Glasius, Geoffrey. "The Movements of 2011: Democracy, Social Justice, Dignity." Development and Change 44 (2013), 547-567.

Podeh, Elie. The Politics of National Celebrations in the Arab Middle East. New York: Cambridge University Press, 2011.

Prinz, Jesse. The Emotional Construction of Morals. New York: Oxford University Press, 2013

Proffitt, Dennis R. "Embodied Perception and the Economy of Action.” Perspectives on Psychological Science 1 (2006), 110-22.

Reed, Edward S. James J. Gibson and the Psychology of Perception. New Haven: Yale University Press, 1988.

Riener, Cedar R., Stefanucci, Jeanine, Proffitt, Dennis R., and Clore, Gerald. "An Effect of Mood on the Perception of Geographical Slant." Cognition and Emotion 25:1 (2011), 174-82.

Rivlin, Leanne. "Found Spaces: Freedom of Choice in Public Life." In Loose Space: Possibility and Diversity in Urban Life, edited by K. A. Franck, Q. Stevens, 38-53. New York: Routledge, 2007.

Rosenberger, Robert. "Why It Takes Both Postphenomenology and STS to Account for Technological Mediation The Case of LOVE Park." In Postphenomenological Methodologies: New Ways in Mediating Techno-Human Relationships, edited by Jesper Aagaard, Jan Kyrre, Berg Friis, Jessica Sorenson, Oliver Tafdrup, Cathrine Hasse, with foreword by Dom Ihde, 171-98. New York: Lexington Books, 2018.

Schindler, Sarah. “Architectural Exclusion: Discrimination and Segregation Through Physical Design of the Built Environment.” The Yale Law Review Journal 124 (2015), 1934-2024. 
Schnall, Simone, Zadra, Jonathan, and Proffitt, Dennis. "Direct Evidence for the Economy of Action: Glucose and the Perception of Geographical Slant.” Perception 39 (2010), 464-82.

Schulkin, Jay. Bodily Sensibility: Intelligent Action. New York: Oxford University Press, 2004.

Schulkin, Jay, Thompson, Barbara, and Rosen, Jeffrey. "Demythologizing the Emotions: Adaptation, Cognition, and Visceral Representations of Emotion in the Nervous System." Brain and Cognition 52 (2003), 15-23.

Shargel, Daniel, and Jesse, Prinz. “An Enactivist Theory of Emotional Content." In The Ontology of Emotions, edited by H. Naar, F. Teroni, 110-29. New York: Cambridge University Press, 2018.

Shenker, Jack. The Egyptians: A Radical Story. New York: The New Press, 2016.

Smith, Naomi Smith and Walters, Peter. "Desire Lines and Defensive Architecture in Modern Urban Environments." Urban Studies 55 (2017), 2980-95.

Sterne, Jonathan. "Urban Media and the Politics of Sound Space." In "Sound in Art and Culture," a special issue of Open: Cahier on Art and the Public Domain (2005), 6-15.

Tadros, Sherine. “Egypt Military's Economic Empire.” Al Jazeera, September 5, 2012. https://www.aljazeera.com/indepth/ features/2012/02/2012215195912519142.html.

Teti, Andrea, and Gervasio, Gennaro. "The Unbearable Lightness of Authoritarianism: Lessons from the Arab Uprisings.” Mediterranean Politics 16 (2011), 321-7.

Sagoff, Mark. "At the Shrine of Our Lady of Fatima or Why Political Questions Are Not All Economic." Arizona Law Review 23 (1981), 1283-98.

Shah, Rajiv, and Kesan, Jay. "How Architecture Regulates." Journal of Architecture and Planning Research 24 (2007), $351-9$. Still, Arthur, and Good, James. "The Ontology of Mutualism." Ecological Psychology 10 (1998), 39-63.

Van den Hoven, Jeroen. "Architecture and Value-Sensitive Design." In Ethics, Design and Planning of the Built Environment, edited by Claudia Basta, Stefano Moroni, 135-41. Dordrecht, Springer, 2013.

Vaughan, Laura. "The Spatial Syntax of Urban Segregation.” Progress in Planning 67 (2007), 205-94.

Walsh, Declan. “Revolt at American University Where Pompeo Addressed Middle East.” New York Times, February 6, 2019. https://www.nytimes.com/2019/02/06/world/middleeast/american-university-cairo-pompeo.html.

Whyte, William. The Social Life of Small Urban Spaces. Washington DC: The Conservation Foundation, 1980.

Winner, Langdon. “Do Artifacts have Politics?” Daedalus 109 (1980), 121-36.

Zadra, Jonathan, Schnall, Simone, Weltman, Arthur, and Proffitt, Dennis. "Direct Physiological Evidence for an Economy of Action: Bioenergetics and the Perception of Spatial Layout." Journal of Vision 10 (2010), 54. 